\title{
O ENAMORAMENTO E A SEPARAÇÃO DOS AMANTES NOS CADERNOS DE PENSAMENTO DE HANNAH ARENDT
}

\author{
The falling in love and the separation of lovers in \\ Hannah Arendt's Notebook of Thought
}

Marion Brepohl*

\begin{abstract}
RESUMO
O presente artigo tem como objetivo apresentar, a partir de algumas passagens dos Cadernos de Pensamento de Hannah Arendt, suas reflexões sobre o enamoramento e a separação dos amantes, sua relevância na vida cotidiana, seu necessário distanciamento em relação à vida pública e suas construções do eu - interior. Não se trata, todavia, de um estudo sobre a intimidade da autora, mas um estudo sobre a intimidade segundo Hannah Arendt.
\end{abstract}

Palavras-chave: Vida Privada; conjugalidade; convivialidade.

\begin{abstract}
This article aims at presenting, from some passages taken from Hannah Arendt's Thoughts Notebook, her ideas about falling in love and the separation of lovers, its relevance to daily life, its necessary distancing from public life and its constructions of one's interior self. It is not, however, a study of the author's intimate life, but a study of intimate life according to Hannah Arendt.
\end{abstract}

Keywords: private life; conjugability; conviviability.

* Professora Associada da Universidade Federal do Paraná e Bolsista do CNPq 
O título deste artigo pode despertar, entre os leitores interessados em Hannah Arendt, a curiosidade e a suspeita de que me dedicarei às suas relações afetivas, que foram em si mesmas exemplo de uma época muito conflitiva: sua relação com Martin Heidegger, com o primeiro marido, Günther Stern e com o segundo marido, Heinrich Blücher, mas principalmente o primeiro, acontecimento que teve uma repercussão ruidosa e polêmica, não apenas por se tratar de uma relação clandestina entre uma jovem aluna (à época, com 18 anos) e um já reputado professor do meio acadêmico alemão, mas também, porque Heidegger, nos anos que se seguiriam, aderiu ao nacional-socialismo, regime que levou Arendt à perseguição e ao exílio. Seu primeiro casamento, com Günther Stern, judeu e intelectual como ela, que tinha tudo para ser duradouro, dada a proximidade de ambas as heranças culturais, mas que terminou muito rapidamente, também nos suscita algumas indagações; ao revés, as relações com Blücher, alemão e de origem operária, e cuja projeção pública sempre ficou muito aquém à de Hannah, fustiga-nos, de semelhante modo, a imaginação, dada a inversão dos papéis convencionais entre marido e esposa.

Além disso, o próprio título do livro - Cadernos de Pensamento, (no sentido literal - diários de pensar) ${ }^{1}$, até pelo fato de ser ela uma mulher, pode vir a sugerir que seu conteúdo tematize as experiências com seus amantes, sua intimidade, seus sentimentos, divagações de caráter auto-biográfico, como é próprio dos diários desde a época do romantismo, escritos na primeira pessoa, prenhe de segredos a serem revelados somente às pessoas próximas e, mesmo assim, como um testamento emocional, a ser lido postumamente, quando a vergonha e o juízo tornam-se menos importantes do que a idealização da pessoa querida.

Por certo, e quem conhece a trajetória de Hannah sabe, que todas as suas experiências pessoais como: a discriminação por ser judia, o exílio, as dificuldades financeiras, a perplexidade com os horrores dos campos de concentração, o estranhamento à cultura norte-americana, sua viagem a Israel para acompanhar o processo Eichmann, esses e tantos outros episódios afetaram profundamente sua escrita e suas atitudes políticas.

Por essas razões, ela mesma declarava não ser exatamente o que se podia chamar de filósofa profissional; era uma pensadora que, em primeiro

1 ARENDT, H. Denktagbuch: 1950-1973. München/ Zürich: Piper, 2003, 2 v. Foi editado por Ursula Ludz und Ingeborg Nordmann. 
lugar, aguçava sua sensibilidade para perceber o que estava acontecendo no mundo para, somente depois de muita reflexão, debates e leituras, manifestar sua compreensão dos fatos - dar sentido à dor, como ela mesma definiu, uma vez, o ato de pensar. ${ }^{2}$

Exatamente por esse motivo, não é de se surpreender que o leitor tenha a expectativa de que estes escritos se configurem como um diário que, como tantos outros, definem-se como um gênero literário intimista, no qual, ao escrevê-lo, o autor, ao mesmo tempo em que apazigua a sua dor, rememora seus momentos de prazer, revela-se a si mesmo - como quem se debruça sobre uma história cujo fim só se pode desejar. ${ }^{3}$ Sobretudo, um gênero que estetiza a história pessoal e introspectiva, quiçá, uma autocelebração, garantindo ao nome de quem o redige, alguma duração. Isto tudo poderia estar presente neste livro, mas não está.

No que concerne à autora, o universo de seus afetos e de incertezas foi, sim, compartilhado não apenas em conversas, mas em correspondências com amigos e amigas, dentre eles, o próprio Heidegger, com quem manteve vínculos até o final de sua vida. A propósito destas, e, embora não seja minha intenção analisar tais cartas, penso, como Igor Caruso, que a correspondência com Heidegger, vinculava-se ao fato de que, quando os amantes se separam e mantêm uma relação epistolar, assim o fazem para construir "uma utopia dentro de si, qual seja, a de superar as forças do esquecimento, da mentira, da posse, da repressão". ${ }^{4}$ É como se o esquecer dele ou dela fosse uma forma de suicidar-se um pouco.

Além disto, muitas destas cartas, tanto no caso específico de Arendt como entre outros amantes em geral, tanto podem ser escritas para o outro como para si mesmo, uma forma, talvez, nem sempre bem sucedida, de superar a saudade e a frustração, como Hannah uma vez afirmou, citando Isak Dinesen: "todas as mágoas são suportáveis quando fazemos delas uma história a seu respeito." 5

Mas apesar de levar muito a sério o amor erótico, é sabido que, exceto para um pequeníssimo círculo de pessoas, no geral, Hannah sempre

2 ARENDT, H. A condição humana. Rio de Janeiro: Forense, 1983. p. 182.

3 Sobre o papel dos diários no cotidiano da vida privada, ver: JAHNEL, Claudia. O arquivamento do eu: o diário de Hugo Delitsch e as lembranças de Emma Anton (1844-1859). Tese (Doutorado em História) - Universidade Federal do Paraná, Curitiba, 2002.

4 CARUSO, Igor. A separação dos amantes. São Paulo: Cortez, 1989. p. 79-80.

5 ARENDT, op.cit., 1983, p. 188. 
se mostrou discreta a respeito de seus próprios sentimentos, avessa à prática de falar sobre sua intimidade. Até sobre o falecimento de Blücher, por exemplo, com quem viveu por 34 anos, seu registro é singelo, quase lacônico, ainda que a expressão de dor lhe escape na citação de apenas três versos. Eu cito:

Em 31 de outubro Heinrich morreu, de repente, muito rápido, em 7 horas e meia. Em 4 de novembro, deram-se suas exéquias, no dia 15 , o seu enterro em Bard.

Alguém se foi com o que era seu;

Em sua montaria, silêncio e melancolia, Depois, ainda o céu e os abutres ${ }^{6}$

Este exemplo demonstra que, malgrado sua educação em uma família liberal, mantinha um distanciamento cortês para com os recém conhecidos, era avessa às fluidas informalidades que recobrem algumas relações interpessoais e submetia-se, não sem alguma relutância, às convenções sociais (talvez tivesse sido essa a razão de submeter-se aos limites impostos por Heidegger para os seus encontros, e também por ter tolerado os casos furtivos de Blücher com outras mulheres). Judia, sim, mas com cultura e hábitos alemães de explicar suas atitudes e comportamentos, de ensinar fosse o que fosse, de evitar expor seu estado de ânimo - que ela julgava ser, ao fim e ao cabo, uma conversa cujo desenlace transformar-se-ia inevitavelmente em mexerico. ${ }^{7}$

Ao invés disso, segundo sua biógrafa Elizabeth Bruehl, Hannah tendia sempre para a generalização, "deixando que as experiências deslizassem para o fundo de sua alma, onde não poderiam feri-la" " Se algum acontecimento lhe tocava, por causar dor ou encantamento, ela procurava

6 No original: Einer zog aus mit Langmut und Schweigen / Dann kamen noch Himmel und Geier dazu. (Trecho da balada de Mazeppa, de Bertold Brecht). Cf. ARENDT, H. Denktagbuch: 1950-1973. München/ Zürich: Piper, 2003. p. 797.

7 A este respeito, cf. ARENDT, Hannah. Rahel Varnhagen: judia alemã na época do Romantismo. São Paulo: Relume Dumarà, 1994. p. 21.

8 BRUEHL, Elizabeth. Hannah Arendt: por amor ao mundo. Rio de Janeiro: Relume Dumarà, 1997. p. 70. 
superar a subjetividade introspectiva por meio de uma história ou de uma poesia, palavras que, elas sim, dotariam o evento de alguma permanência ${ }^{9}$, pois a linguagem lhe soava como a vigia da angústia.

Essa mesma tendência está presente no Caderno de pensamentos; eles não são, portanto, um conjunto de textos de caráter confessional; não estão escritos, a não ser em raros momentos, na primeira pessoa do singular; são apontamentos que, conquanto possam se encontrar alguns poemas, alguns registros de acontecimentos relacionados diretamente à vida cotidiana da autora, devem ser lidos e interpretados como reflexões rápida e sucintamente anotadas, como suporte, como rascunhos de excertos de futuros livros e artigos. Muitos foram aproveitados em seus trabalhos ulteriores, alguns mantidos somente ali, mas desde o início, assim me parece, Hannah pretendia que fossem conhecidos pelos interessados em seu trabalho. Alguns parecem tecer considerações sobre um fato novo, outros, anotados em uma única frase, outros, sob forma de aforismos, não faltando ainda menções a algumas frases de efeito de um autor que lhe despertasse interesse; outros, ainda, podem ser considerados quase que um artigo completo.

Importante mencionar que os cadernos editados em dois volumes referem-se à Hannah madura, pois foram escritos entre os seus 44 e 67 anos.

Em meio às diversas reflexões sobre o tema do amor, cotejei aqueles que se dedicaram ao amor entre duas pessoas, com alguma permanência (real ou imaginária), reciprocidade, intensidade, erotismo. Deixei de lado, propositadamente, as reflexões que derivaram de suas concepções sobre o amor ao mundo - ou seja, a empatia de todo ser humano normal pelo próximo - , inspiradas, principalmente, na obra de Agostinho ${ }^{10}$, cujos escritos foram a base de sua tese de doutorado e cujo tema a autora nunca se lhe deixou escapar. Voltarei a comentar a presença de sua leitura sobre Agostinho, ainda que de forma breve, ao fim deste artigo; agora, quero me deter em seus comentários e considerações sobre o amor dos amantes, o que pode ser lido, entre nós, historiadores, como uma possibilidade, uma inspi-

9 A este respeito, ver a análise de Elizabeth Bruehl sobre a possível projeção das experiências de Hannah com Heidegger ao escrever sobre Rahel: BRUEHL, Elizabeth. Hannah Arendt: por amor ao mundo. Rio de Janeiro: Relume Dumarà,1997. p. 70 et. seq. Ver também: KRISTEVA, Julia. O gênio feminino. Rio de Janeiro: Rocco, 2002. p. 56 et seq.

10 ARENDT, Hannah. O conceito de amor em Santo Agostinho. Lisboa: Instituto Piaget. 
ração para os estudos sobre um campo historiográfico específico - a História da vida privada.

Todavia, antes de mencionar e comentar o que está posto no diário, gostaria de tecer, e essa é uma escolha muito particular de minha parte, algumas ponderações sobre o enamoramento e a separação dos amantes

\begin{tabular}{|c|c|}
\hline $\begin{array}{l}\text { Por que me dás, envergonhado a mão, } \\
\text { como se fosse um segredo? } \\
\text { És de uma terra tão distante que não } \\
\text { conhece nosso vinho? }\end{array}$ & $\begin{array}{l}\text { Warum gibst du mir die Hand } \\
\text { Scheu und wir geheim? } \\
\text { Kommst Du aus so fernem Land, } \\
\text { Kennst nicht unseren Wein? }\end{array}$ \\
\hline $\begin{array}{l}\text { Não conheces nosso mais belo ardor } \\
\text { (Vives tão só?) } \\
\text { Com o coração, com o sangue } \\
\text { Ser um no outro? }\end{array}$ & $\begin{array}{l}\text { Kennst nicht unsere schönste Glut } \\
\text { (Lebst Du so allein?) } \\
\text { Mit dem Herzen, mit dem Blut } \\
\text { Eins im andern sein? }\end{array}$ \\
\hline $\begin{array}{l}\text { Não sabes que o prazer do dia } \\
\text { Anda com os amantes, } \\
\text { Não sabes que a separação da noite } \\
\text { Anda com a total melancolia? }\end{array}$ & $\begin{array}{l}\text { Weisst Du nicht des Tages Freuden } \\
\text { Mit dem Liebsten gehen, } \\
\text { Weisst Du nicht des Abends Scheiden } \\
\text { Ganz in Schwermut gehen? }\end{array}$ \\
\hline $\begin{array}{l}\text { Vem comigo e me ama } \\
\text { Não pensa no que te apavora } \\
\text { Será que não podes te entregar? } \\
\text { Vem e toma e dá }\end{array}$ & $\begin{array}{l}\text { Kommt mit mir und hab mich lieb } \\
\text { Denk nicht am dein Grauen, } \\
\text { Kannst Du Dich denn nicht vertrauen } \\
\text { Komm und nimm und gib. }\end{array}$ \\
\hline $\begin{array}{l}\text { Vamos caminhar pelos campos maduros } \\
\text { com papoulas e trevos selvagens } \\
\text { Mais tarde, lá no longínquo mundo } \\
\text { Ainda sentiremos dor }\end{array}$ & $\begin{array}{l}\text { Gehen dann durchs reife Feld } \\
\text { (Mohn und wilder Klee) } \\
\text { Später in der weiten Welt } \\
\text { Tut es uns noch weh, }\end{array}$ \\
\hline $\begin{array}{l}\text { Quando sentirmos como as lembranças } \\
\text { Como o vento, voam intensamente, } \\
\text { Daí no arrepio fantasticamente suave } \\
\text { Nossa alma voará. }\end{array}$ & $\begin{array}{l}\text { Wenn wir spüren, wie im Wind } \\
\text { Stark Erinnerung weht } \\
\text { Wenn im Schauder traumhaft lind } \\
\text { Unsere Seele weht." }\end{array}$ \\
\hline
\end{tabular}

11 BRUEHL, Elizabeth. Hannah Arendt: por amor ao mundo. Rio de Janeiro: Relume-Dumarà, 1997. p. 421. 
poetizadas por Hannah. Para tanto, creio ser suficiente citar apenas dois exemplos, sendo o primeiro poema, escrito em 1925, e o segundo, em 1951.

Como já mencionei, Hannah foi amante de Heidegger, relação que se manteve por 5 anos, ela, quase uma adolescente, ele, 35 anos, casado e pai de dois filhos.

Relações entre professor e aluna são invariavelmente condenadas, moças apaixonadas por homens mais velhos, são sempre consideradas imaturas ou em busca de um pai; a posição de "amante" é tida, inequivocamente, como uma invasão, o que se faz acompanhar ainda pela suspeita de tratar-se de um interesse escuso, pautado em segundas intenções, e não um amor efetivo.

Hannah cedeu, de forma submissa, aos limites impostos por Heidegger, ou seja, às regras convencionais de uma relação não convencional. O papel de se frustrar, de se deixar magoar, e, por fim, de ser abandonada, como ela o foi, porque Heidegger, segundo Elzibieta Ettinger, apesar da discrição dos encontros, pressionou-a para que deixasse a Unversidade de Marburg. Ele se deixou levar exclusivamente por suas angústias, fosse porque sua esposa já estivesse alimentando suspeitas, fosse porque ele mesmo não suportasse mais a ambigüidade da relação, fosse pelo medo de um escândalo que ameaçasse seu status quo. Pouco importa o motivo: Hannah se sentiu, como era de se esperar, trapaceada e menosprezada. ${ }^{12}$

Provavelmente foi este amor que inspirou o poema que citei, mas não é isso que quero destacar, e sim, seu caráter jovial, quase pueril, ingênuo, como uma típica mocinha a provar-se a si mesma. Alguém que pretende seduzir, com perguntas insidiosas que vão se tornando um convite para um algo que oferece tudo, menos aquilo que quer dar. Em outras palavras, conforme Lacan, ao referir-se ao jogo amoroso, "amar é dar aquilo que não se tem àquele que não é."13

Até a maneira da autora do poema pedir amor é obsequiosa - no original, hab mich lieb, é uma expressão geralmente empregada por crianças ou por pais de crianças, quando querem um simples carinho do outro. Mas já aí, e isso se repete no segundo poema, há um tom de melancolia pela

12 ETTINGER, Elzbieta. Hannah Arendt/Martin Heidegger. Rio de Janeiro: Jorge Zahar, 1996. p. 29 et seq.

13 LACAN, Jacques. O seminário: livro 8. Rio de Janeiro: Jorge Zahar, 1988. p. 126. 
perda. Algo que poderia soar como evidente, pois foi ela a abandonada, mas isso só é evidente na aparência, pois não é apenas de sua condição particular que o poema poetiza, e sim, do próprio amor. Porque em minha opinião, um poema nunca será uma carta de amor: será a universalização desta experiência maior.

A seguir, o segundo poema:

\begin{tabular}{|l|l|}
\hline $\begin{array}{l}\text { Vem e habita } \\
\text { No tortuoso e escuro quarto de meu } \\
\text { coração } \\
\text { Cujas paredes amplas ainda estão } \\
\text { fechadas }\end{array}$ & $\begin{array}{l}\text { Komm und wohne } \\
\text { In der schrägen, dunkeln Kammer } \\
\text { meines Herzens, } \\
\text { Das der Wände Weite noch zum } \\
\text { Raum sich schliesst. }\end{array}$ \\
$\begin{array}{l}\text { Vem e cai } \\
\text { Na colorida profundeza de meu sono } \\
\text { Que se amedronta face ao íngreme } \\
\text { abismo de nosso mundo. }\end{array}$ & $\begin{array}{l}\text { Komm und falle } \\
\text { In die bunten Gründe meines Schlafes, } \\
\text { Der sich ängstigt vor des Abgrunds } \\
\text { Steile unserer Welt. }\end{array}$ \\
$\begin{array}{l}\text { Vem e voa } \\
\text { Nas distantes curvas de minha saudade, } \\
\text { Que o fogo alumia na altura de uma } \\
\text { chama }\end{array}$ & $\begin{array}{l}\text { Komm und fliege } \\
\text { In die ferne Kurven meiner Sehensucht, } \\
\text { Dass der Brand aufleuchte in die }\end{array}$ \\
$\begin{array}{l}\text { Para e fica } \\
\text { Espera, que a chegada inevitavelmente Flamme. } \\
\text { Acontece num lançar-se repentino. }\end{array}$ & $\begin{array}{l}\text { Steh und bleibe. } \\
\text { Warte, dass die Ankunft unentrinnbar } \\
\text { Zukommt aus dem Zuwurf eines } \\
\text { Augenblicks. }\end{array}$ \\
\hline
\end{tabular}

Este poema foi escrito quando Hannah já era casada com Blücher, após a Segunda Guerra, quando tinha 45 anos, e talvez tenha sido escrito para ele, mas também isso não importa. O que interessa é que vem à tona a consciência de quem sabe ter um lado sombrio, desconhecido e confuso, somente passível de ser conhecido no olhar do outro. O mundo e seu abismo, o abismo do totalitarismo, que ela mesma tentou entender durante toda a sua vida; mundo que amedronta e, portanto, perturba a tranqüilidade de

14 Ibid., p. 425. 
seu encontro; mas de novo, a percepção da saudade, da fugacidade do amor. Ao escuro do coração corresponde uma chama que alumia, mas, como toda chama, apaga-se repentinamente.

Dois poemas sem título, sem dedicatória, escritos em dois momentos muito diferentes, mas transmitindo a sensação de que o amor dos amantes implica em perda, a qual abre uma ferida e arrasta consigo o que há de melhor no espaço da intimidade. Algo que é, a meu ver, fruto de seu tempo; naqueles anos, entre as camadas instruídas, (o que passaria a ser bem mais freqüente a partir da geração 68), as relações afetivas se tornavam cada vez mais demandantes de reconhecimento, transparência e satisfação sexual, e qualquer frustração transformava o amor no seu outro, a saber, o menosprezo e o esquecimento, pois afinal,

Eros no puede ser fiel a sí mismo sin practicar la caricia, pero no puede praticarla sin correr el riesgo del dominio. Eros impulsa a las manos a tocarse, pero las manos que acarician tambén pueden oprimir y aplastar. ${ }^{15}$

A propósito, ao fazer um pequeno comentário sobre o deus Eros, Arendt também o identifica como tirânico e perigoso, pois, como em nossos sonhos, o "eu", ou melhor, "nosso eu tirânico" tudo domina. ${ }^{16}$

E, quanto ao esquecimento, e não o ódio (porque odiar o amante é como odiar a si mesmo), é ele o pior castigo. Para aquele que é esquecido, resta-lhe tão somente a dor da saudade que, ao misturar esperança e desespero, ignora o que é passado e o que é futuro.

A saudade, uma das palavras mais significativas da língua e da cultura portuguesa foi poetizada por Francisco Buarque de Hollanda, enquanto algo que dói como

um barco que aos poucos descreve um arco e evita atracar no cais, $[\ldots]$ como o revés de um parto, $[\ldots]$ como arrumar o quarto de um filho que já morreu, [...] como metade amputada de si. ${ }^{17}$

15 BAUMAN, Zygmunt. Amor líquido: acerca de la fragilidad de los vínculos humanos. Buenos Aires: Fondo de Cultura Econômica, 2005. p. 23.

16 ARENDT, H. Denktagbuch: 1950-1973. München/Zürich: Piper, 2003. p. 237, 464.

17 BUARQUE, Chico. Pedaço de mim. In: Perfil. Rio de Janeiro: Som Livre, 1 CD, estéreo. s/d. 
Sobra a iconografia, a contemplação dos objetos ordinários outrora compartilhados, os lugares de memória; ou, em termos psicanalíticos,

Ausente, o amado torna-se de imediato uma imagem insubstituível, única e perdida para sempre; a seguir, será vivido como traidor, mesquinho, omisso e desatento. ${ }^{18}$

Seja idealizado ou castigado dentro de si, seja uma perda ou o um medo angustiante da perda, esses sentimentos significam, a meu ver, que as possibilidades de separação tornaram-se bem maiores à medida que o amor passou, de maneira intensa, ao primeiro plano. E num momento aziago para os europeus, pois no século $\mathrm{XX}$, ocorreram inúmeras separações involuntárias, em virtude da guerra, do exílio, do racismo, da morte e das migrações.

\section{Da intensidade do amor e da separação}

Examinemos, agora, as reflexões de Arendt sobre o amor dos amantes.

Arendt, conforme Wolfgang Heuer, empenhou-se muito

[...] em distinguir as atividades humanas elementares como modalidades da pluralidade. Enquanto atividades elementares, ela especifica cinco: o laborar, o fabricar, o agir, o pensar e também justamente o amar. E ela as define com respeito às relações interpessoais humanas: o laborar, que se define por estar o indivíduo em estado de abandono, exercendo uma atividade de força; o fabricar, em um estado de isolamento, um momento de criação de objetos e obras de arte e se baseia na violência; o agir, em um estado de estar junto, no mundo comum; o pensar, que se dá com o indivíduo em estado de solidão, que, no entanto, experimenta o diálogo consigo mesmo

18 CARUSO, Igor. A separação dos amantes. São Paulo: Cortez, 1989. p. 67. 
e absorve as impressões alheias e, finalmente o amar, $_{2}$ que consiste no estar junto um com o outro, todavia excluindo o mundo, separando-se dos outros. Para Arendt, no laborar as pessoas sempre estão isoladas e acossadas por inquietações $e$ angústias, no fabricar estão sozinhas na liberdade da espontaneidade e inspiradas pela obra como uma criação; no agir estão juntas com outras, face a uma responsabilidade política, e somente no amor "há reciprocidade real que se baseia na necessidade um do outro. Ser uma pessoa quer dizer imediatamente carecer de (outra) pessoa." No amor alguém carece um do outro, enquanto que na pluralidade se é prescindível dos outros. No caso do amor, procura-se a pessoa adequada, no caso da pluralidade, tem que contar-se com o "inadequado", o estranho, o diferente. A diferença fundamental está entre o precisar, que decorre de nossa condição heterossexual, ou pelo menos assim está pré-estabelecida, e por outro lado a dependência um do outro 2 que reside na pluralidade. Sendo assim, conclui Arendt, que laborar, pensar e amar são "os três modi de uma mera vida humana, dos quais nunca poderá nascer um mundo, pois são atividades inerentemente adversas ao mundo, isto é, anti-políticas." ${ }^{19}$

Ao ler estes e outros excertos do Denktagbuch, em especial, os trechos em que ela concede a palavra ao amor entre os amantes e comparando estes textos a algumas cartas e trechos de livros de sua autoria, ela, que é conhecida como teórica do político, avessa à psicologia e à psicanálise $^{20}$, soou-me como inusitado o valor que ela atribui à vida erótica, ao

19 HEUER, Wolfgang. Dogville: humilhação, amor e política; reflexões em diálogo com Hannah Arendt. In: MARSON, Izabel; NAXARA, Márcia. Sobre a humilhação: sentimentos, gestos, palavras. Uberlândia: EDUFU, 2005. p. 313. Ver também as considerações de Arendt sobre o amor, como a mais poderosa força humana, conquanto anti-política em: ARENDT, Hannah. A condição humana. Rio de Janeiro: Forense Universitária, 1983. p. 254.

20 A resistência de Arendt à psicanálise me parece pouco clara e, até um certo ponto, motivada pelo exemplo de atitudes narcisistas de muitas pessoas de classe média de sua época, que procuravam um discurso sobre si através da psicanálise. Mas em suas análises sobre Disraeli, (ARENDT, Hannah. O sistema totalitário. Lisboa: Dom Quixote, 1978, p. 119 et seq.), de Rahel e do próprio Heidegger, quando madura, assim me parece, pode-se observar algumas semelhanças com as reflexões de Freud. Ademais, o peso que confere aos sentimentos, como o ódio racial enquanto sentimento coletivo, podem ser, igualmente, comparados às análises de Freud sobre o medo, a paranóia e o sado-masoquismo. A este respeito, ver: ANSART, Pierre. Hannah Arendt e a obscuridade dos ódios públicos. In: DUARTE, A.; LOPREATO, C.; BREPOHL DE MAGALHÃES, M. A banalização da violência: a atualidade do pensamento de Hannah Arendt. Rio de 
prazer sensível, às relações amorosas - como uma necessidade, necessidade de se compreender e de ser feliz, de haver com quem dividir cumplicidade e interlocução em todas as dimensões que nos afeta enquanto pessoas.

Em outra passagem, ao discutir a diferença entre amor e casamento, ela emprega um termo muito sugestivo, de que o amor não é um sentimento, mas um acontecimento, acontecimento a partir do qual uma história ou um destino vem a se desenvolver. Já o casamento, enquanto instituição.

Tritura o acontecimento, como fazem, aliás, todas as instituições que surgiram de um acontecimento; pois a instituição, que se cria a partir de um acontecimento exige, para que perdure, basear-se na lei. E o casamento, que é uma lei, é a tentativa de institucionalizar o amor.

Contra isto, protestam homens e mulheres, cada um à sua maneira. Ambos tentam evitar a crescente fluidez e perda de substância do amor; as mulheres fazem do amor, que é um acontecimento, um sentimento, o que não apenas degrada o amor, uma vez que transforma algo divino em algo humano, quanto degrada também (igualmente) o próprio sentimento. Porque o (s) sentimento (s), manifestadamente, que servem para medir a intensidade, o fogo do amor, não consegue mantê-lo ou prendê-lo.

$\mathrm{O}$ erro procede do fato de se acreditar que o amor nasce no coração do homem; o coração do homem é seu habitat, mas não sua pátria; $[. .$.$] o protesto dos homens se dirige no sentido$ de transformar o amor em amizade. Esta é precisamente a definição kantiana de casamento, cuja reciprocidade garante um contrato de amizade $[\ldots]^{21}$

Todavia, prossegue ela, nenhuma amizade pode suportar o que o amor suporta, como por exemplo, o fim do casamento enquanto instituição, a falta de garantias, bem como a confiança tão somente no "não esquecer", enquanto que, a confiança, numa relação de amizade, é o que há de mais precioso, e por isso, temos o direito e a necessidade de exigi-lo. Se a amizade, por sua vez, for exigida no cotidiano de uma relação amorosa, ela perece.

Janeiro: Relume Dumarà, 2004. p. 17-34. Sobre as possíveis razões do afastamento de Arendt da psicologia e da psicanálise, ver: KRISTEVA, J. O gênio feminino. Rio de Janeiro: Rocco, 2002. p. 159 et seq.

21 ARENDT, Hannah. Denktagbuch: 1950-1973. München/Zürich: Piper, 2003. p. 49. 
Cita Jaspers, um de seus grandes amigos, para quem

Sentimento, eu tenho. $\mathrm{O}$ amor me tem

Amizade é essencialmente dependente de suas duração - não existe amizade de duas semanas. Já o amor é sempre um coup de foudre 22

Em outra passagem, ela define amor como um poder:

O amor é um poder e não um sentimento. Ele fortalece o coração, porquanto é um raio que desfaz o espaço existencial que existe entre as pessoas. O raio desfaz esse entre, e isso só pode acontecer entre duas pessoas. Esta intimidade realiza um verdadeiro corte, um separar-se do mundo, um quedar-se no oculto, e a única coisa que pode intervir, é seu fruto: uma criança. Mas o nascimento da criança, desfaz o duísmo dos amantes, pois com a criança surge um novo mundo, - ela, em si mesma, um novo mundo. ${ }^{23}$

E, em outra, ela cita o amor, em especial, o amor apaixonado, como padecimento:

Quem está disposto a amar, tem de abandonar tudo, como numa devoção e também se deixar (ou contar com a possibilidade) de levar uma ferroada. ${ }^{24}$

A paixão é precisamente o contrário da ação. Assim como a coragem é a virtude da ação, o padecimento é a virtude da paixão. Paixão está sempre associada ao amor; ... O orgulho de Faulkner é o orgulho do padecimento, o único legítimo. Diz ele: se eu for feliz, serei; se eu tiver de sofrer, sei que serei capaz sofrer. ${ }^{25}$

22 Ibid., p. 51.

23 ARENDT, H. Denktagbuch: 1950-1973. München/Zürich: Piper, 2003. p. 372, 548.

24 Ibid., p. 279.

25 Ibid., p. 526. 
É irresistível, para nós, cuja língua materna é o idioma português, deixar de estabelecer um paralelo entre estes conceitos de Hannah com o poema de Luís de Camões, segundo meu entendimento, um poema que logrou poetizar um conceito:

Amor é um fogo que arde sem se ver,

É ferida que dói, e não se sente;

É um contentamento descontente,

É dor que desatina sem doer.

É um não querer mais que bem querer;

É um andar solitário entre a gente;

É nunca contentar-se de contente;

É um cuidar que ganha em se perder.

É querer estar preso por vontade;

É servir a quem vence, o vencedor;

É ter com quem nos mata, lealdade.

Mas como causar pode seu favor

Nos corações humanos amizade,

Se tão contrário a si é o mesmo Amor?

Neste poema, também se presencia o aspecto da devoção que se oferece ao sofrimento; o fogo que arde entre os amantes; a lealdade, um tanto quanto rápida, mas mesmo assim, por um momento, lealdade, incondicional; a dificuldade, ou mesmo, impossibilidade, de se pensar que do amor resulte a amizade; é (sempre) estar solitário entre a gente - como para Hannah, ficar fora do mundo.Fora do mundo, primeiro, porque toda intimidade, para ser verdadeiramente intimidade, tem de se ocultar. E é ali que o desejo se realiza, 
como divertimento, fuga de si, a vontade de se fixar ao que aparentemente tem permanência. Esta perda caracteriza-se pela curiosidade, a concupiscência do olhar, que procura um saber inútil. $^{26}$

Divertimento que experimenta um momento de pertença, antes da perda, e que tem sua própria linguagem. Sim, porque, enquanto, seja com amigos ou com adversários, conversamos sobre algo, cujo resultado pode ser um consenso ou um dissenso, pouco importa, o importante é que se trata de uma conversa sobre o mundo ou sobre nós no mundo, e o outro é efetivamente um outro ${ }^{27}$, entre os amantes, esta diferenciação se esvai. Quando os amantes conversam, pouco se referem ao mundo, eles poetizam, e, a façanha deste falar, segundo Arendt, "reside no despertar uma agradável surpresa a quem ouve". E sua resposta não é uma réplica, mas uma ressonância. "Trata-se de um compartilhar que vem de lugar nenhum e não chega obrigatoriamente a parte alguma. ${ }^{28}$

Conversa inútil, distraída, mas de forma alguma irrelevante, porquanto nos tornamos mais humanos e, ao mesmo tempo, mais fortes. Em resposta a uma carta de Hannah, Blücher escreve, em 1949, a importância de seu amor e a dor da separação:

o casal multiplica tudo por dois. É uma fórmula verdadeiramente viva, pois ela contém tanto de seriedade e de ironia quanto a própria vida. Quem ia querer levar uma vida simples, se pudesse ter uma multiplicada por dois, e quem acreditaria, ademais, poder usar algo deste tipo? [...] Uma coisa é certa. Uma vez que se começou a viver em dobro, a separação o corta em dois [...] a solidão, tal como nós no-la garantimos mutuamente, e a solidão na qual amaríamos encarar juntos o mundo - as duas se construíram sobre os fundamentos de ser-dois. ${ }^{29}$

26 Apontamentos sobre o amor enquanto desejo em: ARENDT, H. O conceito de amor em Santo Agostinho. Lisboa: Instituto Piaget, 1997. p. 28.

27 ARENDT, H. Denktagbuch: 1950-1973. München/Zürich: Piper, 2003. p. 214.

28 Ibid., p. 214-215.

29 KRISTEVA, Julia. O gênio feminino: Hannah Arendt. Rio de Janeiro: Rocco, 2002. p. 36. 
Então, embora nos tornemos fortes para encarar o mundo, quando se ama, a gente fica inevitavelmente fora do mundo, e daí um pouco fraca, pois o amor, para Hannah, seja um poder, uma atividade, um acontecimento, um padecimento, ele é de origem divina. ${ }^{30}$ É como um raio que acontece e que destrói o espaço entre duas pessoas. E, como raio, é repentino, inusitado e fugaz. E como ato divino, vem do alto.

Ao afirmar que o amor é de origem divina, não está aí realizando uma metáfora. Para ela, o amor é definitivamente divino.

Sobre a experiência da teologia cristã em sua vida, não podemos deixar de lembrar de suas escolhas de juventude: pretendia, originalmente, estudar com o teólogo Rudolf Bultmann e sua tese de doutorado foi sobre Agostinho. Tanto na tese, como no livro $O$ que é política? ${ }^{31}$, ela declara acreditar que há um Criador, o qual nos faz experimentar o amor quando descobrimos nossa interioridade e nossa vontade, tema que ela recupera e aprofunda em Vida do Espírito. ${ }^{32}$ Por isso, somos iguais ao mesmo tempo em que somos diferentes, pois cada criatura de Deus é única e traz consigo a semente de quem a criou - a semente do amor.

Por esta razão, o tema da natalidade é tão precioso para a autora, concreta e simbolicamente. Tudo ou todo o que nasce (seja uma pessoa ou um novo acontecimento), cria algo novo, que muda, em alguma instância, o mundo. E é desta forma que ela compreende a forma com que a chegada de Jesus de Nazaré, cujo grande invento foi o de introduzir a bondade neste mundo, $-\mathrm{o}$ amor ao próximo, tanto quanto a capacidade de prometer e de perdoar ter sido anunciada nos evangelhos nas breves palavras: "alegraivos, nasceu uma criança entre nós". ${ }^{33}$

E quando este mesmo amor chega a alguém, mesmo que se o queira prender, é para cuidar, para proteger. Quando o amor dos amantes nos

30 ARENDT, H., op. cit., 2003, p. 49.

31 ARENDT, Hannah. O que é política? Rio de Janeiro: Bertrand, 1998. p. 21.

32 Ver, em especial, suas reflexões sobre o primado da vontade sobre o intelecto segundo Duns Scotus em: A vida do espírito. Rio de Janeiro: Relume Dumarà, 1992. p. 280 et seq.

33 Cf ARENDT, Hannah. A condição humana. Rio de Janeiro: Forense, 1983. p. 257 et seq. Neste texto, Arendt afirma que conquanto a bondade seja acósmica, expressando-se enquanto caridade, já o poder de perdoar, tanto quanto a capacidade de fazer milagres - o que, no sentido secular, traduzir-se-ia pela capacidade de prometer -, são introduzidos nos negócios humanos - vale dizer - na política. Com estas duas capacidades, mesmo que tenham sofrido mudanças com o processo de secularização, o homem pode se reconciliar com o mundo - no ato do perdão, e no agir conjuntamente com um determinado propósito em nome de um futuro em que se vislumbra o bem comum. 
toca, em momentos raros, mas não menos divinos, experimenta-se o transcendente. Por isso, a promessa de sempre lembrar, de não esquecer, principalmente, da primeira vez.

\section{Algumas molduras para a História da Vida Privada}

Retorno agora ao meu propósito inicial. Após estes breves comentários sobre as principais citações de Hannah sobre o amor, o que nós, historiadores, poderíamos apreender de todas estas dispersas expressões, todas elas, tanto filosóficas quanto poéticas?

Não pretendo concluir à moda acadêmica, ou seja, propondo um encaminhamento metodológico. Apenas apontar algumas sugestões sobre o lugar do amor no moldar das sensibilidades e ações de homens públicos e mulheres públicas.

Primeiramente, a questão da temporalidade. Em sua tradição judaico-cristã, Hannah pensa o lugar da memória - incluindo o lembrar-se de um amante, como uma forma de presentificar o passado. E o passado guarda uma estreita relação com o futuro, se pensarmos no futuro como eternidade. E o que é o amor senão minúsculas eternidades? Por isso, penso que a História da vida privada poderia abarcar não apenas as tendências e comportamentos coletivos, mas também a maneira como as pessoas se amavam e como deram testemunhos deste amor, como fez a própria Hannah Arendt, por exemplo, com respeito a Rahel Varnhagen. Refiro-me aqui não às biografias, mas ao estudo do papel do amor nas vidas singulares.

Por outro lado, creio também que o caso Heidegger e Hannah, já que os historiadores apreciam as regularidades, poderia ser visto não apenas como um mexerico indevido sobre duas vidas públicas, mas como um dado da mentalidade moderna. Hannah cita duas frases engraçadas a respeito de seu ex-amante, que eu gostaria de reproduzir e comentar.

Ao escrever a Jaspers, em 1958, sobre a hostilidade com que Heidegger recebeu o volume de seu livro A condição humana, presenteado por ela, desabafa: 
Eu sei que é intolerável para ele que meu nome apareça em público, que eu escreva livros, etc. Eu realmente lhe menti durante todo o tempo, portando-me como ....se eu não soubesse contar até três, exceto quando se tratasse de dar uma interpretação sobre suas próprias coisas; neste caso, sempre era gratificante para ele quando descobria que eu poderia contar até três e mesmo até quatro. Mas subitamente essa lorota ficou bastante chata para mim e paguei pela minha mudança recebendo um soco no nariz. ${ }^{34}$

E, sobre a influência e controle de Elfriede, esposa de Heidegger, sobre a vida do marido, manifesta seu parecer em uma carta enviada a Blücher em 1952:

É um caso clássico do laço plebe-elite [...] a história toda é uma tragédia [...] Quando imagino que ele retorna necessariamente a tal meio assim que seu trabalho tem uma pausa, isso me deixa simplesmente tonta [...] de que maneira única uma esposa vazia pode destruir tudo: Das nichts nichtet (o nada nadeia). ${ }^{35}$

À parte do senso e humor aí impresso, o que já valeria um estudo, sobre sua impaciência em tolerar visitas sociais quando o que queria mesmo era debater com seu antigo professor, o que quero salientar é este $d u p l o$ (esposa e amante) como um possível lenitivo para compensar muitas escolhas conjugais que partem da desigualdade: um cônjuge (na maioria dos casos, o homem) que se vê superior em inteligência e que espera - e usufrui - dos elogios do parceiro ou da parceira para o engrandecimento de seu ego e para evitar qualquer sorte de conflitos. Por outro lado, constrói um vínculo com outra mulher ou outro homem que, na realidade, não poderia suportar no cotidiano. Esse comportamento me parece típico do século XX, um período de transição entre a tradicional família pequeno-burguesa e os casamentos ou parcerias realizados após o movimento feminista. A este propósito, recordo-me da atriz brasileira Leila Diniz (1945-1972) perseguida

34 BRUEHL, Elizabeth. Hannah Arendt: por amor ao mundo. Rio de Janeiro: Relume-Dumarà, 1997, p. 277.

35 BRUEHL, Elizabeth. Hannah Arendt: por amor ao mundo. Rio de Janeiro: Relume-Dumarà, 1997. p. $276-277$. 
pela polícia política no Brasil à época da ditadura militar, que afirmou: "Os homens é que precisam ser emancipados".

Um outro contributo de Hannah sobre o amor dos amantes, que também poderia ser objeto de nossa reflexão, diz respeito às mudanças recentes nas relações afetivas. Enquanto que para Hannah, estes vínculos ocupavam o espaço da intimidade e se desvelavam como instantes de sacralidade, hoje, o que conta são as sensações, "o gozar a qualquer preço" (para empregar um termo do psicanalista Charles Melman), a repetição intensa de emoções. Para tanto, dispomos de toda uma indústria tecnicamente muito sofisticada, que está a inaugurar uma nova economia psíquica, com conseqüências antropológicas ainda não mensuráveis. Segundo Melman

Até aqui pertencemos a uma cultura fundada na representação, quer dizer, numa evocação, na evocação do lugar onde se mantinha a instância sexual suscetível de autorizar as trocas. Passamos da representação que nos é familiar, costumeira da relação com o sexo, relação da qual apenas nos avizinhávamos, à - parece - preferência por sua presentação. Como com essa "arte anatômica", trata-se agora de buscar o autêntico, em outras palavras, não mais uma aproximação organizada pela representação, mas de ir para o objeto mesmo. Se continuarmos nesta linha, o que marca essa mutação cultural é esse apagamento do lugar de esconderijo próprio a abrigar o sagrado, quer dizer, aquilo pelo que se sustentam tanto o sexo quanto a morte. Assim, o sexo é encarado hoje em dia como uma necessidade, como a fome ou a sede, agora que estão suspensos tanto o limite quanto a distância próprios ao sagrado que o albergava. ${ }^{36}$

Creio ser interessante também investigar este curto período na relação entre amantes que, estende-se de finais da década de 50 e que culmina em 1968: a parceria conjugal entre iguais, que reivindica a interlocução, a igualdade no prazer sensível, a divisão das tarefas domésticas.

Refiro-me aqui não apenas ao movimento feminista, que questionava, à época de Arendt, o poder falocêntrico e demandava experiências, por parte das mulheres, com seus corpos e desejos, mas o ato de pensar

36 MELMAN, Charles. O homem sem gravidade. Rio de Janeiro: Companhia de Freud, 2003. 
juntos como uma atividade tão prazerosa quanto outras, por amor ao mundo e por amor a alguém como ele (ou ela) é, embora este como é, redefinase a cada olhar do amado ou da amada. ${ }^{37}$

Não estou afirmando com isto que o movimento feminista tenha se equivocado ao politizar as demandas femininas por uma existência mais autônoma em relação aos homens. Apenas ressalto que, em suas palavras de ordem, seus slogans, suas mobilizações, o Movimento Feminista, ao reivindicar direitos para as mulheres, raramente citava, como o fez Leila Diniz, que os homens precisavam se emancipar, para que se tornassem capazes de um encontro entre iguais.

E finalmente, para concluir, eu gostaria de problematizar, senão mediatizar as conclusões de Richard Senett sobre o refluxo à vida privada no século XX, principalmente entre as classes médias norte-americanas. Para Senett, principalmente nos Estados Unidos, desde finais do século XIX, o triunfo do privado sobre o público, a recusa à participação na vida pública, em favor da hipertrofia (ou a tirania) da intimidade, resultou num enorme comportamento narcisista. Para ele, a emergência deste imaginário social, levou ao triunfo da personalidade sobre a ação coletiva, o enclausuramento da família nuclear e a crença nas personalidades como responsáveis pela história.

Isto porque, segundo o autor,

Em resposta ao medo da vacuidade [da aspereza da vida pública], as pessoas concebem o político como um domínio em que a personalidade será declarada vigorosamente. Assim, elas se tornarão os espectadores passivos de uma personalidade política que lhes ofereça suas intenções, seus sentimentos, mais do que seus atos, para a consumação delas. ${ }^{38}$

37 Sobre a importância conferida por Arendt ao amor ao mundo (dilector mundi), ver: ARENDT, Hannah. O conceito de amor em Santo Agostinho. Lisboa: Instituto Piaget, 2002. p. 93 et seq. Sobre o querer que o outro seja o que ele é (volo ut sis), ver: LÜTKEHAUS, Ludger. Ich will, dass du seiest, was Du bist. Hannah Arendt - Martin Heidegger: eine Liebe in Deutschland. Text + KRITIK; Zeitschrift für Literatur. München: Richard Boorberg Verlag, IX: 166-67, 2005. p. 28 et seq.

38 SENETT, Richard. O declínio do homem público. São Paulo: Companhia das Letras, 1988. p. 319 . 
Creio que vidas singulares contrariam esta tendência. Muitos da geração de Arendt e outros mais próximos de nosso tempo fizeram de sua vida a dois uma possibilidade de expressar-se e de interferir fortemente no espaço público, não como herói individual e voluntarista, mas como perfis a animarem a ação coletiva, vale dizer, o próprio espaço público. Cito, além do casal Arendt/ Blücher, Martin e Coretta King, John Lennon e Yoko Ono, o casal Jaspers, Michèlle e Pierre Ansart, além de tantos outros casais, particularmente no Brasil, como o jovem Francisco Buarque de Hollanda e Marieta Severo, Ruy Guerra e Leila Diniz, Clarice e Wladimir Herzog ou Herbert de Souza e Irles Coutinho Carvalho, que se dedicaram ao seu amor e à amizade pelo mundo, resistindo, corajosamente, como pares, à ditadura. 